\title{
Kecerdasan Tradisional dalam Mitigasi Bencana Erupsi pada Masyarakat Lereng Baratdaya Gunungapi Merapi
}

\author{
SRIADI SETYAWATI, HERU PRAMONO,DAN ARIF ASHARI \\ Jurusan Pendidikan Geografi \\ Fakultas Ilmu Sosial Universitas Negeri Yogyakarta \\ sriadi_s@uny.ac.id
}

\begin{abstract}
Abstrak
Penelitian ini bertujuan: (1) mengidentifikasi berbagai bentuk kecerdasan tradisional dalam mitigasi bencana pada masyarakat lereng baratdaya Gunungapi Merapi dan menganalisis maknanya berdasarkan kajian geomorfologi, (2) mengetahui tingkat pemahaman masyarakat generasi muda mengenai kecerdasan tradisional dalam mitigasi bencana erupsi. Penelitian ini menggunakan metode deskriptif-eksplanatif. Pengambilan data dilakukan dengan wawancara, studi pustaka, dokumentasi, dan observasi. Analisis yang digunakan adalah kombinasi antara analisis deskriptif kualitatif dengan kuantitatif. Penaksiran makna dilakukan dengan pendekatan hermeneutika dan semiotika geomorfologi. Hasil penelitian ini telah menemukenali beberapa bentuk kecerdasan tradisional dalam mitigasi bencana pada masyarakat lereng baratdaya Gunungapi Merapi. Kecerdasan tradisional tersebut berbentuk semiotika kultural, semiotika faunal, semiotika vegetal, dan semiotika fisikal. Semiotika kultural berupa nasihat dan ajaran masyarakat, semiotika faunal berupa perilaku berbagai jenis hewan, semiotika vegetal berupa kondisi tumbuhan alami mupun budidaya, dan semiotika fisikal berupa tanda alam yang banyak terjadi sebelum erupsi. Pengetahuan generasi muda terhadap kecerdasan tradisional yang terdapat dalam masyarakat umumnya masih rendah.
\end{abstract}

Kata kunci: Gunungapi Merapi, Kecerdasan Tradisional, Erupsi

\begin{abstract}
This research aim to: (1) identify various forms of people's traditional intelligence in disaster mitigation on southwestern flank of Merapi Volcano and analyze its meaning based on the study of geomorphology, (2) know the level of understanding of the younger citizen about the people's traditional intelligence in mitigation of eruption disaster. This research employs descriptive-explanative method. Data were collected by using interview, literature study, documentation, and observation. The analysis employs combination of quantitative and qualitative descriptive analysis. The interpretation of the meaning of traditional intelligence utilizes the hermeneutics and semiotics based on geomorphological approach. This research has identified some types of people's traditional intelligence in disaster mitigation on southwestern flank of Merapi Volcano. The type of traditional intelligence include: cultural semiotics, faunal semiotics, vegetal semiotics, and physical semiotics. Cultural semiotics consist of people's teaching and advice, faunal semiotics include animal behaviour, vegetal semiotics deal with the condition of the plants and physical semiotics is related to the natural signs before eruption.The understanding of the younger citizen is generally low.
\end{abstract}

Keywords: Merapi Volcano, Traditional Intelligence, Eruption 


\section{PENDAHULUAN}

Salah satu dampak dari letak Indonesia yang berada pada pertemuan tiga lempeng besar dunia adalah tingginya potensi bencana akibat vulkanisme. Sejak masa lampau peristiwa vulkanisme telah banyak mempengaruhi kehidupan masyarakat baik dalam arti positif maupun negatif. Indonesia dengan 129 gunungapi aktif (17\% gunungapi di dunia) merupakan salah satu wilayah dengan potensi bencana vulkanik tertinggi di dunia (Van Padang, 1983: 3-6; Sudibyakto, 1997: 1; Verstappen 2013: 67). Diantara wilayahwilayah Indonesia potensi bencana vulkanik paling banyak terdapat di Pulau Jawa yang merupakan pusat konsentrasi penduduk. $\mathrm{Pu}$ lau Jawa memiliki 23 gunungapi tipe $\mathrm{A}$, dan berdasarkan sejarah erupsi pernah mengalami 470 kali erupsi atau $47 \%$ dari erupsi total yang pernah terjadi di Indonesia (Vestappen, 1994: 27; Verstappen, 2013: 67).

Gunungapi Merapi yang terletak di perbatasan Provinsi Jawa Tengah dan DIY merupakan gunungapi yang sangat aktif. Sejak tahun 1006 Gunungapi Merapi terus mengalami letusan secara reguler dengan rentang antara satu hingga tujuh tahun sekali dan hingga saat ini tercatat telah mengalami letusan hingga lebih dari 80 kali. Atas dasar inilah Merapi sering disebut sebagai never sleeps volcano yang merupakan salah satu gunungapi paling aktif selama holosen. Erupsi Merapi selama ini umumnya mengarah ke lereng barat atau baratdaya (Andreastuti dkk, 2006: 202; Sudradjat dkk, 2010: 69 ; Sudibyakto, 2011a: 117).

Walaupun memiliki potensi bencana yang sangat tinggi, wilayah sekitar Gunungapi Merapi banyak ditempati oleh penduduk. Berbagai peninggalan masyarakat masa lampau yang dijumpai menunjukkan setidaknya telah adanya hunian sejak tahun 800-an masehi yang berlanjut secara turun temurun hingga sekarang. Bahkan pertumbuhan penduduk di daerah bahaya erupsi Merapi ratarata mencapai $2,8 \%$, melebihi pertumbuhan penduduk rata-rata nasional sebesar 2,5\%. Banyaknya penduduk yang bertempat tinggal di wilayah ini tidak terlepas dari adanya faktor penarik berupa potensi sumberdaya alam yang sangat banyak (Degroot, 2009: 12-15; Sutikno dkk, 2007: 33-34;Sudibyakto, 2011b:91). Sebagai masyarakat yang telah menempati kawasan rawan bencana secara turun temurun dan berulang kali mengalami bencana erupsi, diduga terdapat kecerdasan tradisional dalam menghadapi bencana yang terbentuk sebagai hasil pengenalan masyarakat terhadap lingkungan fisiknya. Terlebih wilayah lereng baratdaya pada masa lampau merupakan daerah paling banyak terkena dampak bencana erupsi. Kecerdasan tradisional (local genius) merupakan kecerdasan dalam pengelolaan lingkungan untuk menjaga keseimbangan alam yang sudah lama dikerjakan oleh suatu masyarakat sehingga sudah menjadi budaya setempat. Kecerdasan tradisional juga dikenal sebagai kecerdasan tradisional(local wisdom), pengetahuan lokal (local knowledge), dan pengetahuan asli daerah (indigeneous knowledge) (Sunarto, 2008: 323).

Kecerdasan tradisional merupakan aset yang dapat dikelola dalam membangun sistem manajemen kebencanaan berbasis masyarakat khususnya pada tahap mitigasi bencana. Kecerdasan tradisional terbentuk dari hasil interaksi masyarakat dengan lingkungan fisiknya dalam waktu yang lama. Terbentuknya kecerdasan tradisional memungkinkan masyarakat untuk dapat mengenal dan membaca tanda-tanda alam yang berkaitan dengan bencana erupsi Gunungapi Merapi. Oleh karena pemahaman masyarakat terhadap lingkungannya cukup baik maka pengelolaan kebencanaan dengan mengacu pada karakteristik interaksinya masyarakat dengan lingkungan setempat dapat lebih efektif apabila diterapkan. Berkaitan dengan tujuan tersebut, kecerdasan tradisional yang telah ada perlu untuk digali dan disampaikan agar dipahami oleh generasi penerus.

Selain dapat diterapkan dalam sistem pengelolaan kebencanaan, dalam konteks sosial-budaya kecerdasan tradisional juga merupakan kekayaan yang perlu dipertahankan. Kecerdasan tradisional menunjukkan adanya sistem sosial dan budaya masyarakat di Indonesia yang berkaitan erat dengan lingkungan sehingga memberikan ciri 
spesifik.Namun demikian pada era dengan kemudahan akses informasi seperti saat ini kecerdasan tradisional mulai kurang tersampaikan kepada generasi penerus. Upaya menemukenali kecerdasan tradisional khususnya terkaitdengan pengelolaan lingkungan dan kebencanaan sangat bermanfaat untuk menggali kekayaan sistem sosial budaya masyarakat.

\section{METODE}

Penelitian ini merupakan penelitian deskriptif-eksplanatif. Metode deskriptif digunakan untuk menjelaskan gejala-gejala yang dijumpai secara terperinci. Metode deskriptif dikombinasikan dengan metode eksplanatif, yang berusaha mengungkap sebab akibat yang timbul secara empirik di lapangan (Sunarto, 2011: 7-8). Penelitian ini dilakukan dengan pendekatan geografi yaitu pendekatan ekologi dimana kecerdasan tradisional sebagai permasalahan yang akan diteliti terbentuk dari hasil interaksi antara manusia dengan lingkungan fisik.

Populasi dalam penelitian ini adalah selu- ruh masyarakat di wilayah lereng baratdaya Gunungapi Merapi. Pengambilan sampel dilakukan dengan cara purposif sampling. Untuk mendapatkan data mengenai kecerdasan tradisional dalam masyarakat sampel dipilih dari tokoh masyarakat dan anggota masyarakat lansia sebagai responden. Sedangkan untuk mendapatkan data mengenai tingkat pemahaman masyarakat khususnya generasi muda mengenai kecerdasan tradisional dalam mitigasi bencana sampel dipilih dari anggota masyarakat usia 17 - 40 tahun.

Data yang dikumpulkan adalah data kualitatif yang berkaitan dengan kecerdasan tradisional, yaitu berupa nasihat, filosofi hidup, pepatah, ajaran, perilaku hewan, termasuk pula toponimi daerah; serta data kuantitatif mengenai pemahaman masyarakat terhadap kecerdasan tradisional yang variasinya dipengaruhi oleh usia, tingkat pendidikan, pekerjaan, dan aspek sosial-kependudukan lainnya. Pengumpulan data dilakukan dengan teknik wawancara, studi pustaka, dokumentasi, dan observasi.

Tabel 1. Hubungan antara Penanda dan Petanda

\begin{tabular}{ll}
\hline \multicolumn{1}{c}{$\begin{array}{c}\text { Penanda (wujud/bentuk, } \\
\text { signifier) }\end{array}$} & \multicolumn{1}{c}{ Petanda (arti konseptual, signified) } \\
$\begin{array}{l}\text { Ada awan } \mathrm{Cb} \text { (Cumulonimbus) } \\
\text { Tampak tanah sawah retak-retak }\end{array}$ & $\begin{array}{l}\text { Hari akan hujan } \\
\text { Terjadi kekeringan (penguapan lebih tinggi } \\
\text { daripada hujan }\end{array}$ \\
\hline
\end{tabular}

Sumber: Sunarto (2011: 6)

Analisis dilakukan dengan kombinasi antara analisis deskriptif kualitatif dan kuantitatif. Analisis kualitatif dilakukan untuk menjawab permasalahan pertama. Sunarto (2011: 8) menjelaskan analisis kualitatif dilakukan dengan penalaran induktif-deduktif dan penafsiran penyajiannya tidak dalam bentuk peta maupun tabel. Untuk memberikan penafsiran kecerdasan tradisional, analisis kualitatif didukung dengan penafsiran yang mengacu pada pendekatan hermeneutika dan semiotika kebencanaan. Penggu- naan pendekatan hermeneutika dan semiotika dilakukan dengan mengacu pada metode Sunarto (2011: 6), yaitu dalam semiotika kebencanaan diidentifikasi berbagai bentuk kecerdasan yang sesuai dengan semiotika natural (semiotika faunal, semiotika vegetal, dan semiotika fisikal) dan semiotika kultural (semiotika normatif dan semiotika sosial). Analisis semiotika didukung dengan fenologi dan fenomenologi. Fenologi merupakan ilmu yang mempelajari pengaruh iklim atau lingkungan sekitar terhadap penampilan 
organisme atau populasi, sedangkan fenomenologi merupakan ilmu tentang fenomena, yang mengacu kepada "yang tampak" (Sunarto, 2011: 6-7). Dalam analisis semiologi ter- dapat dikotomi penanda dan petanda (Tabel 1), sedangkan analisis semiotika terdapat trikotomi ikon, indeks, dan simbol (Tabel 2).

Tabel 2. Trikotomi untuk Analisis Semiotika

\begin{tabular}{llll}
\hline Macam tanda: & \multicolumn{1}{c}{ Ikon } & \multicolumn{1}{c}{ Indeks } & \multicolumn{1}{c}{ Simbol } \\
\hline Penciri: & $\begin{array}{l}\text { Kesamaan atau kemiripan } \\
\text { dengan obyek }\end{array}$ & $\begin{array}{l}\text { Hubungan sebab } \\
\text { akibat }\end{array}$ & Konvensi \\
Proses analisis: & $\begin{array}{l}\text { Dapat dilihat langsung } \\
\text { kesamaan atau kemiripan } \\
\text { dengan obyek }\end{array}$ & $\begin{array}{l}\text { Dapat } \\
\text { diinterpretasi, } \\
\text { diduga, ataupun } \\
\text { diperkirakan }\end{array}$ & $\begin{array}{l}\text { Harus dipelajari } \\
\text { terlebih dahulu }\end{array}$ \\
Contoh: & $\begin{array}{l}\text { Foto udara, citra satelit, } \\
\text { peta }\end{array}$ & $\begin{array}{l}\text { Asap dengan api, } \\
\text { sungai keruh }\end{array}$ & $\begin{array}{l}\text { Bunyi } \\
\text { kentongan, } \\
\text { sirine }\end{array}$ \\
\hline
\end{tabular}

Sumber: Sunarto (2011: 7)

Adapun untuk analisis hermeneutika, penafsiran makna yang terkandung di balik tanda-tanda (khususnya semiotika kultural yang berupa nasihat-nasihat) harus menghindari tafsir yang bersifat subyektif. Oleh karena itu dalam hermeneutika kebencanaan diperlukan latar belakang ilmu yang kontekstual. Landasan ilmu yang dapat digunakan adalah geomorfologi. Sehingga pendekatan hermeneutika kebencanaan yang digunakan adalah hermeneutika geomorfologis (Sunarto, 2011: 5).Untuk menjawab permasalahan ke dua digunakan analisis deskriptif kuantitatif.

\section{HASIL DAN PEMBAHASAN}

Kecerdasan tradisional dalam mitigasi bencana pada masyarakat lereng baratdaya Gunungapi Merapi

Penelitian ini merupakan sebagian dari hasil penelitian mengenai kajian kecerdasan tradisional masyarakat dalam mitigasi bencana erupsi pada lereng baratdaya Gunungapi Merapi Kabupaten Magelang. Secara khusus wilayah kajian dalam penelitian ini dibatasi pada tiga desa yang terletak di antara Sungai Putih dan Sungai Blongkeng, dari keseluruhan wilayah kajian yang meliputi tu- juh desa di Kawasan Rawan Bencana (KRB) III Kecamatan Srumbung, antara Sungai Krasak dan Sungai Blongkeng. Secara astronomis daerah penelitian terletak pada 427300 MT hingga 434000 MT serta 9162000 MU hingga $9164000 \mathrm{MU}$ dalam koordinat UTM zona 49 M.Secara geologis daerah penelitian tersusun oleh material Endapan Gunungapi Merapi Muda (Qmi), Endapan Longsoran dari Awan Panas (na), dan Kubah lava dan leleran (d). Secara geomorfologis di daerah penelitian terdapat bentuklahan kepundan, medan lahar, medan lava, kerucut gunungapi, lereng gunungapi, kaki gunungapi, dataran kaki gunungapi, dan perbukitan terisolasi. Berdasarkan klasifikasi iklim Schmidt-Ferguson daerah penelitian termasuk dalam tipe Iklim C, sedangkan menurut klasifikasi iklim Oldeman termasuk dalam tipe iklim B2. Daerah penelitian ditunjukkan oleh Gambar 1 berikut ini.

Hasil penelitian ini telah menemukenali beberapa bentuk kecerdasan tradisional dalam mitigasi bencana, pada masyarakat lereng baratdaya Gunungapi Merapi. Kecerdasan tradisional tersebut berbentuk semiotika analitik dan deskriptif. Semiotika anali- 
tik atau semiotika natural berupa semiotika faunal, vegetal, dan fisikal. Adapun semiotika deskriptif atau semiotika kultural berupa semiotika sosial dalam bentuk ajaran-ajaran atau nasehat dari generasi terdahulu mengenai tanda-tanda akan terjadi bencana erupsi dan penanganannya.

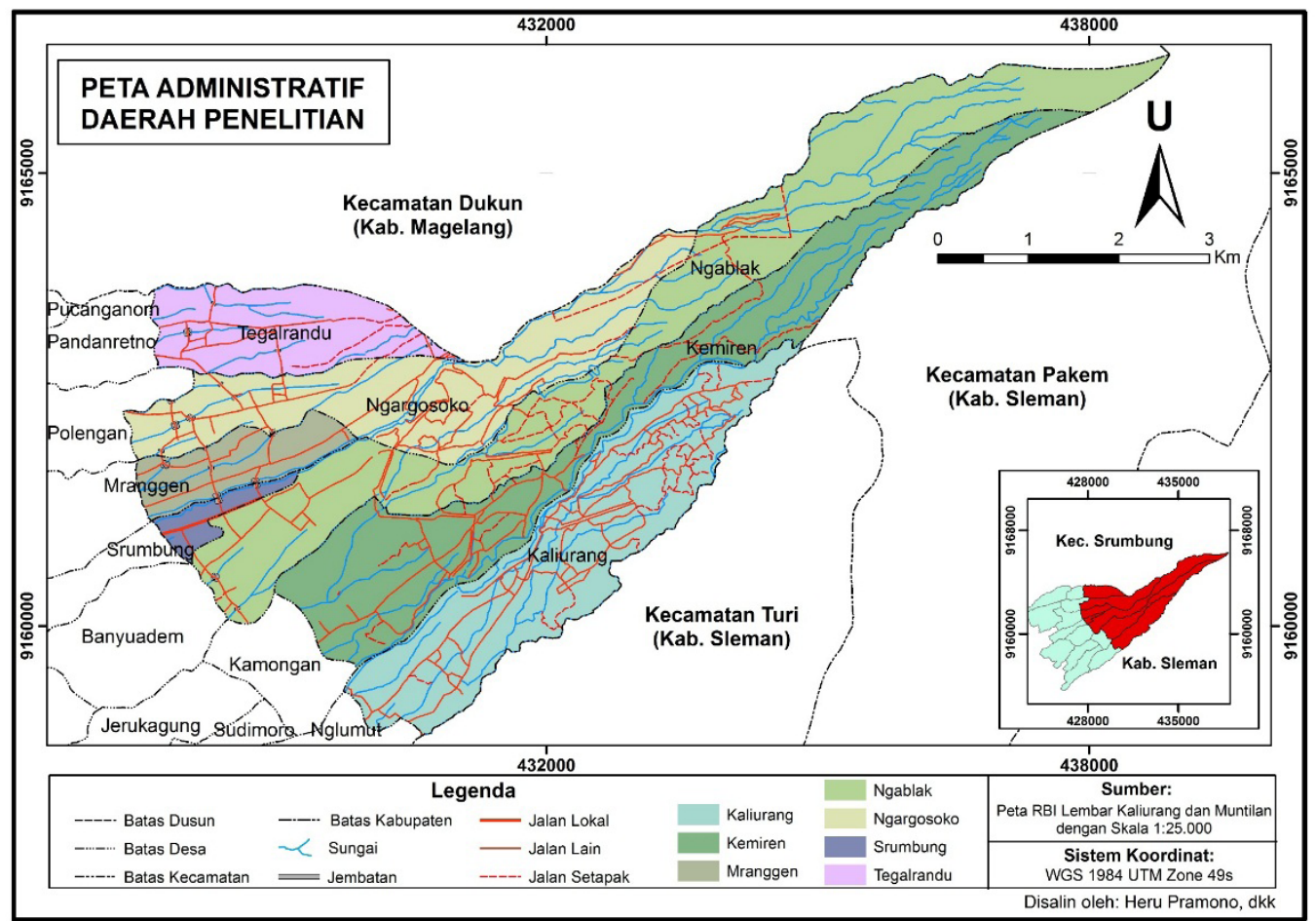

Gambar 1. Daerah penelitian, ditandai dengan lingkaran dan anak panah meliputi Desa Ngargosoka, Desa Mranggen, dan Desa Tegalrandu

Semiotika faunal berupa perilaku hewan yang dipahami dan diinformasikan secara turun temurun dalam masyarakat. Masyarakat umumnya memahami bahwa sebelum terjadi bencana erupsi hewan-hewan dari Gunungapi Merapi akan turun menjauhi sumber bahaya hingga mencapai permukiman atau daerah pertanian masyarakat. Namun demikian, terdapat variasi pemahaman mengenai perilaku hewan ini. Pemahaman lebih mendalam yang dijumpai di beberapa desa menunjukkan, gejala turunnya hewan dari Gunungapi Merapi membentuk kelompok-kelompok tertentu serta kadang-kadang terdapat jenis hewan tertentu yang tidak biasa dijumpai pada saat Gunungapi Merapi dalam status aktif normal. Menurut kunci dikotomi Saussure, turunnya hewan-hewan merupakan penanda, sedangkan peristiwa erupsi yang akan terjadi merupakan petanda. Apabila mengacu pada indeks dalam analisis semiotika Pierce, terdapat hubungan sebab akibat antara hewan yang turun menjauhi Gunungapi Merapi dengan akan terjadinya erupsi. Hal ini berdasarkan dugaan kondisi lingkungan fisik di daerah Gunungapi Merapi tidak dalam kondisi yang cukup baik untuk mendukung kehidupan hewan-hewan tersebut sebagaimana biasanya pada saat status Gunungapi Merapi aktif normal.

Semiotika fisikal berupa tanda-tanda alam khususnya berkaitan dengan cuaca dan kondisi bentanglahan. Umumnya sebelum terjadi erupsi, masyarakat telah dapat memperkirakan berdasarkan suhu udara yang lebih panas dibandingkan dengan harihari biasanya, terdengar suara gemuruh dari arah Gunungapi Merapi, serta terjadi 
kilat. Disamping pengenalan tanda-tanda yang bersifat umum, terdapat pula pengenalan tanda yang spesifik hanya dijumpai di salah satu desa daerah penelitian yaitu debit mataair yang berkurang dan permukaan air sumur masyarakat yang semakin dalam. Kondisi lingkungan fisik ini merupakan penanda sedangkan akan terjadi erupsi merupakan petanda. Kondisi lingkungan fisik juga berhubungan sebab akibat terhadap akan terjadinya erupsi. Sebagai contoh, suara gemuruh disertai gempa tremor di wilayah Gunungapi Merapi tidak terlepas dari proses naiknya magma menuju kepundan. Gempa tremor dapat menyebabkan gangguan terhadap perlapisan batuan sehingga menyebabkan permukaan air sumur lebih dalam, dan beberapa mataair menurun debitnya. Kilat yang banyak terbentuk walaupun tidak pada musim penghujan terjadi karena terdapat gelombang elektromagnetik yang dipancarkan pada saat terjadi erupsi.

Semiotika vegetal berupa kondisi tumbuhan khususnya tanaman pertanian masyarakat yang dapat digunakan sebagai penanda akan terjadinya bencana erupsi. Pengenalan tanda-tanda dari karakteristik tumbuhan ini tidak banyak dijumpai di daerah penelitian. Gejala yang dijumpai antara lain terdapat jenis hama tanaman tertentu, serta tumbuhan yang mati karena kering atau layu. Semiotika kultural dijumpai dalam bentuk nasihat-nasihat yang seringkali dituturkan dengan tambahan mitos-mitos tertentu. Semiotika kultural sangat sulit ditemukan karena kurangnya pemahaman masyarkat serta tidak adanya pengajaran secara turun temurun. Hal ini diduga dapat pula terjadi karena nasihat yang mengandung mitos relatif sulit untuk diterima oleh masyarakat.

Semiotika fisikal di Desa Mranggen dijumpai dalam berbagai bentuk antara lain suhu udara yang lebih panas ketika akan terjadi erupsi, permukaan air sumur menjadi lebih dalam, debit mataair berkurang, dan sering terdengar suara gemuruh dari Gunung Merapi. Tanda-tanda ini digunakan masyarakat untuk mengenali kondisi yang menunjukkan peningkatan aktivitas vulkanik Gunung Merapi. Selain itu juga terdapat semiotika vegetal yang ditunjukkan oleh kondisi vegetasi yang tiba-tiba layu dan kering. Semiotika faunal berupa perilaku hewan yang menjauhi Gunung Merapi hingga mencapai permukiman masyarakat juga dijumpai di Desa Mranggen. Hewan-hewan yang menjauhi Gunung Merapi terdiri dari berbagai jenis yaitu kera, harimau, ular, bahkan sebelum terjadi bencana biasanya terdapat kupukupu kuning dalam jumlah sangat banyak terbang berkelompok ke arah selatan. Apabila sudah mulai terdapat tanda-tanda akan terjadi erupsi maka masyarakat tidak boleh melakukan aktivitas seperti mencari rumput atau menambang di dekat gunung. Anakanak juga tidak boleh bermain di dekat sungai karena banjir lahar dapat terjadi sewaktu-waktu.

Semiotika kultural di Desa Mranggen berupa nasihat-nasihat yang diajarkan turun temurun. Salah satu diantaranya adalah kepercayaan bahwa pasca terjadinya erupsi akan ada proses arak-arakan dari Gunung Merapi ke Laut Selatan. Berdasarkan kepercayaan masyarakat, arak-arakan terjadi karena pada saat erupsi sebenarnya Gunung Merapi sedang melaksanakan hajatan yang berhubungan dengan laut selatan.Nasihat mengenai arak-arakan ini apabila dipahami tanpa adanya penafsiran memungkinkan terjadinya penyimpangan arti. Oleh karena itu diperlukan hermeneutika kebencanaan yang didasarkan pada keilmuan di bidang geomorfologi atau hermeneutika geomorfologis. Hermeneutika diartikan sebagai cara berpikir filsafati dalam memahami realitas yang terkandung di balik kata (bahasa), pengalaman hidup sehari-hari, sejarah, seni, serta berbagai fenomena hidup lainnya. Dengan hermeneutika dapat dijabarkan lebih lanjut tentang makna filsafati dengan berdasar pada ilmu-ilmu yang melandasinya (Sunarto, 2011: 3).

Berdasarkan penafsiran dengan landasan keilmuan geomorfologi, arak-arakan yang dimaksud merupakan aliran lahar hujan yang mengalir melalui lembah-lembah sungai dari pembongkaran material endapan piroklastik oleh hujan. Aliran lahar berupa aliran debris dan konsentrasi sedimen tinggi (Sutikno dkk, 
2007: 26) termasuk bongkah batuan dengan berbagai ukuran sehingga dianalogikan sebagai arak-arakan yang terdiri dari rombongan dengan kendaraan yang melintasi jalan. Lebih lanjut, nasihat tersebut menjelaskan bahwa apabila terjadi arak-arakan makaakan ada banyak orang yang berjalan ke arah selatan, disertai dengan suara yang timbul tenggelam seperti suara anjing yang melolong pada malam hari, suara gamelan, ataupun suara orang menangis. Nasihat mengenai banyak orang yang berjalan ke arah selatan juga dapat dimaknai sebagai aliran lahar hujan yang banyak membawa material berbagai ukuran dalam jumlah banyak. Aliran lahar hujan biasanya juga terjadi hingga beberapa jam sehingga jumlah material yang terangkut cukup banyak. Aliran lahar menimbulkan suara gemuruh sehingga oleh masyarakat ditafsirkan dengan berbagai macam suara.

Bentuk semiotika kultural lainnya yang terdapat di Desa Mranggen adalah penataan ruang permukiman yang membentuk pola-pola tertentu. Di Dusun Grogolsari, Desa Mranggen, bangunan-bangunan permukiman ditempatkan menghadap ke jalan dan mengelompok dengan harapan mempermudah proses evakuasi dan pertukaran informasi mengenai aktivitas gunungapi pada saat terjadi erupsi.

Semiotika fisikal dan faunal juga masih dijumpai di Desa Ngargosoka dan Tegalrandu tetapi relatif tidak banyak dikembangkan dalam kaitnnya dengan penanggulangan bencana. Bentuk semiotika fisikal yang masih dikenali adalah suhu udara meningkat menjelang terjadi erupsi, sedangkan semiotika faunal berupa hewan-hewan yang berasal dari Gunung Merapi turun hingga ke permukiman masyarakat. Hewan tersebut terdiri dari berbagai jenis, termasuk beberapa jenis burung yang jarang dijumpai di wilayah desa tersebut dalam kehidupan sehari-hari. Kecerdasan tradisional yang berupa nasihat-nasihat pada saat ini sudah mulai banyak berkembang dengan latar belakang keagamaan Islam.

\section{Tingkat pemahaman generasi muda terh- adap kecerdasan tradisional masyarakat}

Berbagai bentuk kecerdasan tradisional dalam pengelolaan bencana yang telah ditemukenali di lereng baratdaya Gunungapi Merapi Kecamatan Srumbung, tidak begitu dipahami oleh generasi muda di wilayah tesebut. Berdasarkan analisis hasil wawancara terhadap responden generasi muda dengan usia 20 tahun hingga 40 tahun di daerah penelitian, diketahui hanya 33,34\% responden yang memahami adanya kecerdasan tradisional, 35,71\% mengetahui adanya kecerdasan tradisional namun tidak memahaminya dan umumnya hanya pernah mendengar dari anggota masyarakat yang lebih tua. Sebanyak 30,95\% responden lainnya tidak memahami tentang keberadaan kecerdasan tradisional dan maknanya, walaupun hanya dalam tingkatan sekedar pernah mengetahui. Tingkat pemahaman generasi muda terhadap kecerdasan tradisional di daerah penelitian ditunjukkan oleh Tabel 3 .

Tabel 3.

Tingkat pemahaman generasi muda terhadap kecerdasan tradisional dalam pengelolaan bencana

\begin{tabular}{lccc}
\hline & \multicolumn{3}{c}{ Kriteria tingkat pemahaman } \\
\cline { 2 - 4 } \multicolumn{1}{c}{ Desa } & Memahami & Mengetahui & Tidak Mengetahui \\
\hline Mranggen & $4,76 \%$ & $21,42 \%$ & $7,14 \%$ \\
Ngargosoka & $4,76 \%$ & $4,76 \%$ & $23,81 \%$ \\
Tegalrandu & $23,81 \%$ & $9,52 \%$ & $0 \%$ \\
\hline Jumlah & $33,34 \%$ & $35,71 \%$ & $30,95 \%$ \\
\hline Sumber: Hasil analisis data lapangan (2014)
\end{tabular}


Dari 33,34\% responden yang memahami tentang kecerdasan tradisional, umumnya bentuk yang dipahami hanyalah semiotika faunal dan semiotika fisikal. Desa Tegalrandu merupakan desa yang paling banyak memiliki responden memahami kecerdasan tradisional. Namun demikian pengetahuan tersebut juga masih terbatas pada semiotika faunal dan semiotika fisikal. Tanda-tanda dari perilaku hewan cenderung banyak dibicarakan dalam masyarakat, sedangkan tanda-tanda fisik pernah dijumpai dan dirasakan sendiri oleh generasi muda.

Bentuk semiotika faunal yang dipahami masih terbatas pada turunnya hewan-hewan menjauhi pusat bahaya erupsi Gunungapi Merapi sebagai tanda akan terjadinya erupsi. Umumnya responden memahamitandatanda ini namun belum pernah menjumpai sendiri secara langsung. Responden yang memahami hanya memperoleh keterangan berdasarkan cerita dari generasi terdahulu. Bentuk perilaku hewan lainnya yang terdapat di daerah penelitian seperti kupu-kupu kuning yang bergerak menjauhi Gunung Merapi dan jenis hama tertentu yang muncul sebelum terjadinya erupsi tidak diketahui sebagai bentuk semiotika faunal lainnya. Pada saat ini tanda-tanda akan terjadinya erupsi dari perilaku hewan semakin jarang dijumpai, diduga karena pengaruh perubahan kondisi ekosistem di wilayah Gunungapi Merapi yang menjadi ancaman terhadap kelestarian hewan tersebut.

Berbeda dengan semiotika faunal, semiotika fisikal masih dirasakan langsung pada saat akan terjadi bencana erupsi. Bentuk semiotika fisikal yang dipahami adalah suhu udara panas dan suara gemuruh dari arah Gunung Merapi apabila akan terjadi bencana erupsi. Kondisi lingkungan fisik seperti suhu udara yang semakin panas serta terdengar suara gemuruh dari arah Gunungapi Merapi merupakan gejala yang banyak terjadi dan dirasakan langsung sebelum terjadi erupsi. Namun demikian tanda-tanda ini dalam beberapa kasus masih diabaikan oleh generasi muda karena masih kurangnya pemahaman dan pengetahuan. Walaupun kondisi lingkungan fisik tersebut dirasakan sendiri secara langsung tetapi seringkali belum disadari dan dipahami sebagai salah satu tanda akan terjadi erupsi.

Bentuk kecerdasan tradisional lainnya berupa semiotika vegetal dan semiotika kultural tidak banyak dipahami oleh generasi muda. Tanda-tanda yang berasal dari kondisi tumbuhan (semiotika vegetal) merupakan gejala yang sangat jarang dijumpai dan tidak banyak dibicarakan dalam masyarakat sehingga kurang dikenali oleh generasi muda. Adapun semiotika kultural yang berupa nasihat dan ajaran-ajaran dalam masyarakat tidak banyak dipahami oleh karena kurangnya pengajaran dari generasi terdahulu.

Pengetahuan dan pemahaman generasi muda terhadap kecerdasan tradisional di daerah penelitian berhubungan dengan usia dan tingkat pendidikan. Dari jumlah responden yang memahami kecerdasan tradisional, seluruhnya berusia antara 30-40 tahun, sedangkan pada kelompok usia 20-30 tahun tidak dijumpai responden yang memahami tentang kecerdasan tradisionaltersebut. Pemahaman pada kelompok usia yang lebih tua dapat terjadi karena pengalaman menghadapi bencana erupsi yang lebih banyak. Hal ini disebabkan karena penuturan dari orang tua biasanya bersamaan dengan terjadinya bencana erupsi. Adapun pada saat tidak terjadi erupsi, sangat jarang ada pembicaraan yang berkaitan dengan tindakan untuk menghadapi bencana erupsi. Beberapa responden key person juga menyampaikan bahwa pengetahuan dan pemahaman yang diperoleh dari generasi terdahulu mengenai kecerdasan tradisional masyarakat dalam menghadapi bencana erupsi umumnya juga bersamaan dengan peristiwa erupsi. Sementara itu dalam kaitannya dengan tingkat pendidikan, responden yang memahami tentang kecerdasan tradisional umumnya berpendidikan SLTA atau lebih tinggi.

Dalam upaya pelestarian kecerdasan tradisionalumumnya responden antusias untuk berpartisipasi. Hal ini didasari oleh beberapa sebab antara lain: (1) kecerdasan tradisional merupakan bentuk kebudayaan yang telah ada secara turun temurun sehingga perlu dilestarikan, (2) kecerdasan tradis- 
ional merupakan salah satu elemen penting untuk pengembangan sistem pengelolaan kebencanaan, dalm hal ini kecerdasan tradisional dapat dimanfaatkan untuk peningkatan kapasitas masyarakat dalam menghadapi bencana erupsi, (3) sebagai salah satu bentuk kebudayaan masyarakat setempat, kecerdasan tradisional juga dapat dikelola sebagai daya tarik wisata.

Kendala yang dihadapi dalam pelestarian kecerdasan tradisional pada generasi muda terutama adalah masih kurangnya pengajaran dari generasi terdahulu. Saat ini pemahaman mendalam mengenai kecerdasan tradisional dalam menghadapi bencana erupsi masih terbatas pada tokoh masyarakat ataupun anggota masyarakat lansia. Dengan demikian perlu adanya metode penyampaian secara terstruktur agar dapat tersampaikan dengan baik terhadap generasi muda, mengingat antusiasme generasi muda cukup tinggi dalam melestarikan kecerdasan tradisional sebagai aset budaya.

\section{PEMBAHASAN}

Kecerdasan tradisional merupakan salah satu aset penting dalam pengembangan sistem pengelolaan kebencanaan. Sartini (2004: 112) menjelaskan bahwa kecerdasan tradisional atau kearifan lokal terbentuk dari keunggulan budaya masyarakat setempat maupun kondisi geografis dalam arti luas. Fidiyani dan Kamal (2012: 426) menambahkan bahwa munculnya kearifan lokal pada suatu masyarakat atau komunitas pada awalnya terjadi karena manusia berusaha menyesuaikan diri dengan lingkungan geografis tempat tinggalnya dan pengaruh lain yang mengganggu stabilitas budaya setempat. Oleh karena terbentuk dari interaksi masyarakat dengan kondisi geografis tersebut maka dengan kecerdasan tradisional masyarakat memiliki pemahaman yang baik terhadap lingkungannya. Hal ini memberikan modal yang sangat berharga untuk pengembangan pengelolaan kebencanaan yang efektif. Dalam kaitannya dengan pengelolaan kebencanaan, Sartini (2004: 112113) menjelaskan terdapat beberapa aspek dalam kearifan lokal yaitu (1) sebagai kon- servasi dan pelestarian sumberdaya alam, (2) pengembangan sumberdaya manusia, (3) pengembangan kebudayaan dan ilmu pengetahuan, serta (4) petuah, kepercayaan, sastra, dan pantangan. Kepercayaan tradisional berdasarkan keterangan Lavigne dkk (2008: 273) berpengaruh terhadap persepsi masyarakat terhadap bencana yang selanjutnya mempengaruhi perilaku jangka pendek masyarakat dalam menghadapi bencana.

Kecerdasan tradisional berdasarkan hasil penelitian dijumpai dalam berbagai bentuk antara lain nasihat dan mitos, perilaku hewan, kondisi vegetasi, dan kondisi lingkungan alam. Nasihat dan mitos dalam masyarakat muncul berkaitan dengan kepercayaan akan terjadinya arak-arakan pasca erupsi yang bersumber dari Gunung Merapi hingga Laut Selatan. Keterangan ini masih bersifat multitafsir sehingga perlu dimaknai dengan dasar konsep geomorfologi yang menunjukkan adanya bahaya akibat aliran lahar. Sunarto (2008: 326) menjelaskan kebenaran tafsiran dapat diperoleh dengan didukung tingkat pengetahuan dan pengalaman, pendalaman sejarah, pemahaman bahasa dan budaya, serta lingkungan pergaulan. Sunarto (2008: 327-331) juga menjelaskan bahwa kecerdasan tradisional termasuk di dalamnya yang berupa nasihat seperti dijumpai di daerah penelitian, telah banyak berkembang dalam masyarakat dan bermanfaat dalam peringatan dini ancaman bencana, mitigasi bencana, serta antisipasi bencana. Hasil penelitian ini menunjukkan kecerdasan tradisional masyarakat secara khusus memiliki fungsi antisipasi bahaya sekunder pasca erupsi yaitu aliran lahar. Penyampaian nasihat seringkali dikaitkan dengan mitos-mitos tertentu. Hal ini disebabkan karena mitos memiliki pengaruh yang kuat terhadap masyarakat tradisional, sebagaimana pendapat Bing (2014: 4) dan Donovan (2010: 122) tentang mitologi yang dipercayai oleh masyarakat di Gunung Merapi dan berbagai wilayah lain yang berkaitan.

Nasihat tersebut diajarkan secara turun temurun walaupun penyebarannya cenderung terbatas. Penyampaian nasihat dilakukan dengan penuturan lisan. Penuturan lisan 
ini berdasarkan keterangan Donovan (2010: 122) berfungsi sebagai peringatan tradisional. Nasihat seringkali berkaitan dengan mitos maupun peristiwa bencana masa lampau yang masih diingat oleh masyarakat.

Penyampaian kecerdasan tradisional secara turun temurun pada masyarakat di kawasan rawan bencana Gunung Merapi merupakan gejala yang berlaku umum sebagaimana kearifan masyarakat lainnya di Indonesia. Hal ini sama dengan kearifan yang dijumpai di berbagai wilayah di Indonesia yang juga diajarkan secara turun temurun seperti di Pantai Utara Jawa (Sunarto, 2011: 9), Masyarakat Baduy (Permana dkk, 2011: 67), masyarakat di Kalimantan, Bali, Lombok, Maluku, Papua, dan daerah lainnya yang berkembang terus-menerus dalam kesadaran masyarakat (Sartini, 2004: 113).

Perilaku hewan yang banyak dijumpai berdasarkan pengalaman masyarakat adalah turunnya berbagai jenis hewan bersama kelompoknya masing-masing menjauhi $\mathrm{Gu}$ nung Merapi. Hewan-hewan tersebut berpindah tempat hingga mencapai lahan pertanian masyarakat maupun permukiman. Khusus di Desa Mranggen dijumpai kelompok kupukupu kuning yang terbang menjauhi Gunung Merapi sebelum terjadinya erupsi. Fenomena turunnya berbagai jenis hewan ini oleh masyarakat dikenali sebagai salah satu tanda akan terjadinya erupsi. Sunarto (2011: 10) menjelaskan perilaku hewan sebagai petanda dalam semiologi Saussure atau indeks dalam analisis semiotika Pierce, adapun erupsi gunungapi merupakan petanda. Perilaku hewan merupakan bentuk adaptasi tingkah laku hewan akibat tanggapannya terhadap kondisi lingkungan. Lebih lanjut, Sunarto (2011: 1011) menjelaskan karena fenomena semacam ini berulang-ulang terjadi maka masyarakat telah mengingat-ingat peristiwa tersebut dan disimpan dalam ingatannya sebagai "simpanan" atau dalam istilah jawa "simpenan" atau istilah lainnya "pa-rimbu-an" atau "pasimpen-an" yang kemudian karena berubah bunyi "parimbuan" menjadi "perimbon" atau "primbon". Semiotika faunal selanjutnya menjadi pedoman bagi masyarakat dalam menghadapi bencana. Bahkan berdasarkan pendapat Donovan (2010: 122) tanda-tan- da dari perilaku hewan memiliki pengaruh kuat terhadap peringatan tradisional yang berkembang dalam masyarakat akan datangnya bencana erupsi.

Kondisi lingkungan alam yang berfungsi sebagai tanda akan terjadinya erupsi antara lain suhu udara yang semakin panas dan sering terdapat suara gemuruh disertai kilat dari arah Gunung Merapi. Fenomena ini relatif banyak dipahami oleh masyarakat dan juga berpengaruh terhadap berkembangnya peringatan tradisional (Donovan, 2010: 122). Adapun tanda-tanda yang berasal dari kondisi vegetasi dibandingkan dengan tanda-tanda dari sumber lainnya cenderung paling sedikit dijumpai dan dipahami oleh masyarakat.

\section{SIMPULAN}

Di wilayah lereng baratdaya Gunungapi Merapi terdapat berbagai bentuk kecerdasan tradisionaldalam kaitannya dengan mitigasi bencana erupsi yaitu nasihat dan petunjuk masyarakat (semiotika kultural), perilaku hewan (semiotika faunal), kondisi vegetasi alami dan budidaya (semiotika vegetal), dan kondisi lingkungan fisik (semiotika fisikal). Semiotika kultural berupa nasihat tentang adanya arak-arakan pasca terjadi bencana erupsi dan nasihat tentang penanganan situasi darurat bencana berdasarkan pengalaman bencana erupsi terdahulu. Arakarakan dimaknai sebagai aliran banjir lahar hujan yang terdiri dari material debris dan sedimen konsentrasi tinggi. Semiotika faunal berupa perilaku berbagai jenis hewan yang menjauhi Gunungapi Merapi sebagai penanda akan terjadinya bencana erupsi. Semiotika vegetal berupa kondisi tanaman budidaya yang menurun kualitasnya walaupun dengan kuantitas yang relatif sama dibandingkan panen sebelumnya, atau vegetasi alami yang layu dan kering sebelum terjadi bencana erupsi. Semiotika fisikal berupa tanda-tanda alam yang banyak terjadi sebelum erupsi seperti suhu udara lebih panas, suara gemuruh dari gunung, permukaan air sumur lebih dalam, dan debit mataair berkurang.

Diantara berbagai kecerdasan tradisional tersebut, bentuk kecerdasan yang masih dipahami oleh generasi muda antara lain semiotika faunal berupa perilaku hewan dan 
semiotika fisikal dari tanda-tanda alam berupa suhu udara yang semakin panas pada saat akan terjadi bencana erupsi gunungapi. kecerdasan tradisional dalam mitigasi bencana kurang dipahami oleh generasi muda karena tidak adanya pengajaran dari generasi sebelumnya. Namun demikian, generasi muda saat ini antusias untuk ikut berpartisipasi dalam pelestarian kecerdasan tradisional tersebut sebagai kekayaan budaya, aset pengelolaan kebencanaan, serta daya tarik wisata.

\section{UCAPAN TERIMA KASIH}

Dalam kesempatan ini penulis mengucapkan terima kasih kepada Fakultas Ilmu Sosial, Universitas Negeri Yogyakarta, yang telah memberikan biaya bagi pelaksanaan penelitian ini melalui hibah penelitian kelompok tahun 2014. Penulis juga menyampaikan terima kasih kepada berbagai pihak yang telah membantu pelaksanaan penelitian ini.

\section{DAFTAR PUSTAKA}

Andreastuti, S,D., Newhall, C., dan Dwiyanto, J. 2006. "Menelusuri Kebenaran Letusan Gunung Merapi 1006". Jurnal Geologi Indonesia Vol 1 No 4: 201-207.

Bing, J.B. 2014. "Mixing Knowledge to Negotiate With and on a Volcano". Journal of Alpine ResearchVol 102 No 4: 1-9.

Degroot, V.M.Y. 2009. "Candi Space and Landscape: A Study on the Distribution, Orientation, and Spatial Organization of Central Javanese Temple Remains". Disertasi. Universiteit Leiden. www.openaccess. leidenuniv.nl.diunduh tanggal 9 Oktober 2013.

Donovan, K. 2010. “Doing Social Volcanology: Exploring Volcanic Culture in Indonesia". Area Vol 42 No 1: 117-126.

Fidiyani, R. dan Kamal, U. 2012. "Penjabaran Hukum Alam Menurut Pikiran Orang Jawa Berdasarkan Pranata Mangsa". Jurnal Dinamika Hukum Vol 12 No 3: 421436.

Lavigne, F., Coster, B.J., Juvin, N., Flohic, F., Gaillard, J.C., Teixer, P., Morin, J., dan Sartohadi, J. 2008. "People's Behaviour in the Face of Volcanic Hazards: Perspectives From Javanese Communities, Indonesia".
Journal of Volcanology and geothermal ResearchVol 172 (2008): 273-287.

Permana, R.C.E., Nasution, I.P., dan Gunawijaya, J. 2011. "Kearifan Lokal Tentang Mitigasi Bencana Pada Masyarakat Baduy". Makara Sosial Humaniora Vol 15 No 1: 67-76.

Sartini. 2004. "Menggali Kearifan Lokal Nusantara Sebuah Kajian Filsafati". Jurnal FilsafatVol 37 No 2: 111-120.

Sudibyakto. 1997. Manajemen Bencana Alam dengan Pendekatan Multidisiplin: Studi Kasus Bencana Gunung Merapi. Majalah Geografi IndonesiaVol 12 No 22: 31-41.

Sudibyakto. 2011'a "Risiko Bila Merapi Meletus". dalam Manajemen Bencana Indonesia Kemana?. Yogyakarta: Gadjah Mada University Press.

Sudibyakto. 2011". "Persepsi Penduduk Merapi". dalam Manajemen Bencana Indonesia Kemana? Yogyakarta: Gadjah Mada University Press.

Sudradjat, A., Syafei, I., dan Paripurno, E.T. 2010. The Characteristics of Lahar in Merapi Volcano, Central Java as the Indicator of the Explosive during Holocene. Jurnal Geologi Indonesia Vol 6 No 2: 6974.

Sunarto. 2008. Kecerdasan Tradisional untuk Kajian Kebencanaan dalam Perspektif Hermeneutika. Jurnal Kebencanaan Indonesia Vol 1 No 5: 323-334.

Sunarto. 2011. Pemaknaan Filsafati Kearifan Lokal untuk Adaptasi Masyarakat Terhadap Ancaman bencana Marin dan Fluvial di Lingkungan Kepesisiran. Forum Geografi Vol 25 No 1: 1-16.

Sutikno., Santosa, L.W., Widiyanto., Kurniawan, A., dan Purwanto, T.H. 2007. "Kerajaan Merapi" Sumberdaya Alam dan Daya Dukungnya. Yogyakarta: BPFG UGM.

Van Padang, M.N. 1983. History of Volcanology in the East Indies. Scripta Geologica Vol 71 (1983): 1-81.

Verstappen, H.Th. 1994. The Volcanoes of Indonesia and Natural Disaster Reduction With Some Examples. The Indonesian Journal of Geography Vol 26 No 68: 27-35.

Verstappen, H. Th. 2013. Garis Besar Geomorfologi Indonesia, Terjemahan oleh Sutikno. Yogyakarta: Gadjah Mada University Press. 